
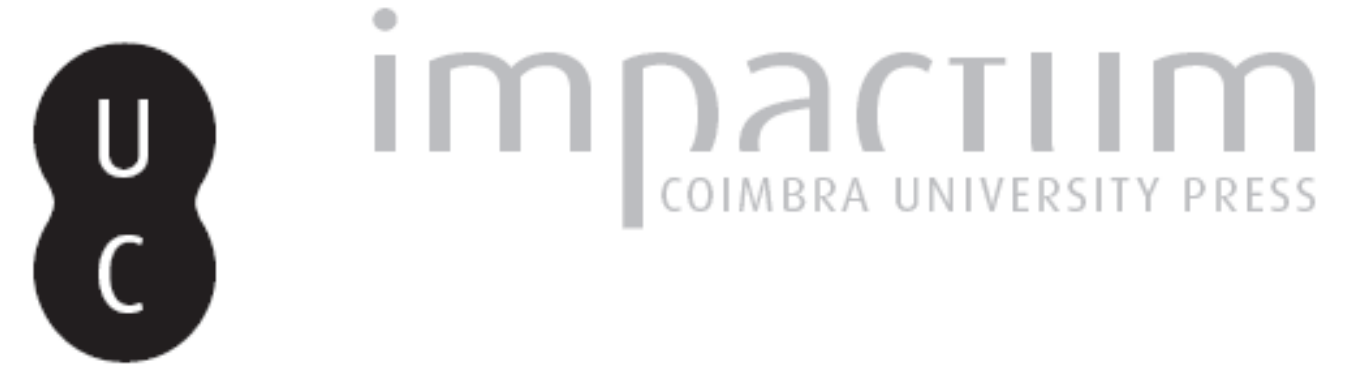

\title{
Tuberculosis in Britain: its history and palaeoepidemiology
}

Autor(es): Roberts, Charlotte

Publicado por: CIAS - Centro de Investigação em Antropologia e Saúde

URL persistente:

URl:http://hdl.handle.net/10316.2/41265

DOI:

DOI:http://dx.doi.org/10.14195/2182-7982_19_9

Accessed : $\quad$ 26-Apr-2023 11:26:54

A navegação consulta e descarregamento dos títulos inseridos nas Bibliotecas Digitais UC Digitalis, UC Pombalina e UC Impactum, pressupõem a aceitação plena e sem reservas dos Termos e Condições de Uso destas Bibliotecas Digitais, disponíveis em https://digitalis.uc.pt/pt-pt/termos.

Conforme exposto nos referidos Termos e Condições de Uso, o descarregamento de títulos de acesso restrito requer uma licença válida de autorização devendo o utilizador aceder ao(s) documento(s) a partir de um endereço de IP da instituição detentora da supramencionada licença.

Ao utilizador é apenas permitido o descarregamento para uso pessoal, pelo que o emprego do(s) título(s) descarregado(s) para outro fim, designadamente comercial, carece de autorização do respetivo autor ou editor da obra.

Na medida em que todas as obras da UC Digitalis se encontram protegidas pelo Código do Direito de Autor e Direitos Conexos e demais legislação aplicável, toda a cópia, parcial ou total, deste documento, nos casos em que é legalmente admitida, deverá conter ou fazer-se acompanhar por este aviso. 
Antropologia Portuguesa

Volume $19 \cdot 2002$

Departamento de Antropologia | Universidade de Coimbra 


\title{
Tuberculosis in Britain: \\ its history and palaeoepidemiology
}

\author{
Charlotte Roberts \\ Department of Archaeology \\ University of Durham \\ Durham DH1 3LE, United Kingdom \\ c.3.roberts@durham.ac.uk
}

Abstract This paper considers the evidence for tuberculosis in skeletal samples from Britain dating from the Romano-British (c. $4^{\text {th }}$ century AD) to the post-Medieval periods (after the $16^{\text {th }}$ century AD). Distribution patterns for the evidence are considered followed by a consideration of the origin of tuberculosis in Britain and its palaeoepidemiology. General increases in frequency of tuberculosis through time are seen with a northern distribution trend developing from an initial south and east focus. The contribution of tuberculous animals to the infection load in humans, and the relationship of leprosy to tuberculosis are considered, with further work being recommended to clarify previous assumptions. Limitations of the data are discussed.

Key words Tuberculosis; Roman; Medieval; palaeoepidemiology; origin.

Resumo Este trabalho apresenta evidências de tuberculose em amostras de esqueletos Britânicos datadas desde o período Romano-Britânico ( $c a$. séc. IV) até ao pós-Medieval (posterior ao séc. XVI). São ainda considerados os padrões da distribuição da tuberculose na Grã-Bretanha, bem como a sua origem e paleoepidemiologia. $O$ aumento geral da frequência da tuberculose através dos tempos é visto como uma tendência de expansão para norte a partir de um foco inicial a sul e a leste. A contribuição de animais tuberculosos, como via de transmissão da infecção para os humanos, e a relação entre a lepra e a tuberculose são, também, abordadas, recomendando-se futuros trabalhos que permitam clarificar as conjecturas actuais. As limitaçōes da amostra são igualmente discutidas.

Palavras-chave Tuberculose; Romano; Medieval; paleoepidemiologia; origem. 


\title{
Introduction
}

\begin{abstract}
"Any anthropologist that hopes to shed light on the etiology and transmission of infectious disease must ultimately accept both a macrosociological perspective... [of] disease ecology and development - and a microsociological perspective...the study of the individual manifestations of culturally prescribed behaviour patterns...seen as risk...or...limiting factors for the contraction of infection" (Inlhorn and Brown, 1990: 98).
\end{abstract}

The infectious disease tuberculosis (TB) has been the focus of palaeopathological research for many years (e.g. Buikstra, 1981). Recently it has also been the disease of choice in attempting to amplify ancient DNA of the infecting organism from both skeletal and mummified remains (e.g. Haas et al., 1999). A re-emerging infectious disease today (Farmer, 1999), and of great concern globally in both developed and developing countries, tuberculosis is a complex disease epidemiologically speaking and was likely devastating to past populations as it is today.

This paper focuses on one country in Europe and aims to document the distribution of skeletal tuberculosis and consider its origin and palaeoepidemiology with reference to its relationship to leprosy, recent research on the evolution of $\mathrm{TB}$, and the distribution of TB in Europe. The data for this paper derives from Roberts and Buikstra (2003).

\section{Material and methods}

The data considered in this paper derive from published and unpublished work, and only those cases of TB diagnosed with Pott's disease of the spine, i.e. tuberculosis, were considered. Possible tuberculous joints and non-specific bone changes such as new bone formation on ribs were not considered specific enough to make a diagnosis of tuberculosis.

Comments are necessary about the data to be considered and a reminder of the general problems of diagnosis in 
palaeopathology. While clinical data guide our disease diagnoses, because of this the absolute frequency of disease and how it affects the skeleton, and the subtle bone changes not visualised on a radiograph, will not necessarily be documented. In collecting the data for this research it also became clear that criteria used by researchers to identify and report skeletal $\mathrm{TB}$ are not standard by any means. For example, most of the earlier work consulted relied heavily, if not exclusively, upon the presence of Pott's disease of the spine. While Pott's disease remains the main area of the skeleton used for diagnosing $T B$, recent studies of skeletons clinically diagnosed as suffering from TB have identified rib periostitis as a possible indicator, although the correlation is not perfect (Roberts, 1999; Santos, 2000; Santos and Roberts, 2001). Furthermore, Larsen (1997:103), when discussing the evidence for tuberculosis at Moundville reported by Powell (1988), suggested that if a large number of individuals in a population have lesions on their ribs, this might suggest, that there is a broader presence of the disease in that particular population, if there is clear evidence of tuberculosis in the group. At this point it should be stated that only a handful of the British cemetery sites revealing TB had recorded rib periostitis but that may be because people do not like examining ribs and it is only recently that these lesions have been a focus of attention in the literature (and many of the sites considered here were analysed many years ago). There are of course other bone changes such as those associated with hypertrophic pulmonary osteoarthropathy (Resnick and Niwayama, 1995), and endocranial new bone formation (Schultz, 1999), which may both be associated with tuberculosis.

It is also important to be aware that the absence of reported TB cases for particular regions and time periods in Britain may reflect a number of factors unrelated to ancient health. Poor preservation or destructive mortuary rituals may lead to limited archaeological recovery of skeletal remains, and areas in the north and west of Britain have soils which do not preserve bone well. Furthermore, affected individuals may have died before TB was registered in osseous tissue. Another limiting issue involves the fact that only a small percentage of people with tuberculosis have skeletal 
involvement (Resnick, 1995) so, because there is potentially so little skeletal evidence of this infection, it is questionable whether the archaeological evidence is representative of the population as a whole. These and other factors described in Wood ct al.'s (1992) "osteological paradox" must be prominent when considering the evidence. Finally, the data described necessarily focuses on cases of $\mathrm{TB}$ and not absolute frequency rates, i.e. the number of spines observed and the number affected with Pott's disease. This is a considerable limiting factor and one that it is not easy to overcome because of the way in which data is presented.

Thus, despite the evidence from human remains being the primary source of information for tuberculosis, we see only a fraction of the people affected in the past through the skeletal record. Absence of evidence, of course, is not evidence of absence. Thus, reconstructing the history of tuberculosis, where it came from and went to and when, therefore is difficult.

\section{Results}

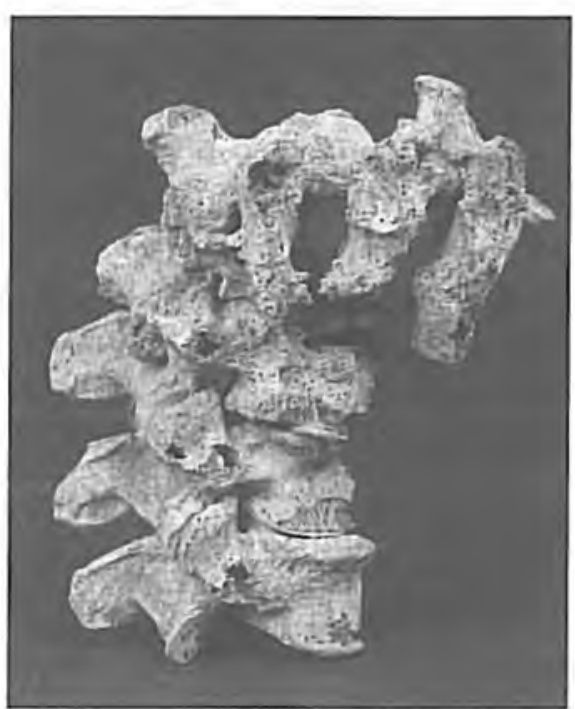

Figure 1. Pott's disease of the spine in an early Medieval individual from Hampshire.
Britain, having had a long history of palaeopathological study, has provided quite a substantial amount of evidence of tuberculosis with all cases deriving from settled agriculturally based rural or urban communities. The following results refer only to Pott's disease (Figure 1) identified in British skeletal material; possible tuberculous joints and the non-specific bone changes such as rib periostitis were not considered specific enough to make a diagnosis of TB. Frequencies 
seem to increase through time (Figure 2). In addition to the definite cases of tuberculosis, there were a number of other sites revealing possible cases of tuberculosis, depending on what criteria are accepted for diagnosis. The following discussion focuses on the main findings from the data and particular skeletons that are unique or unusual.

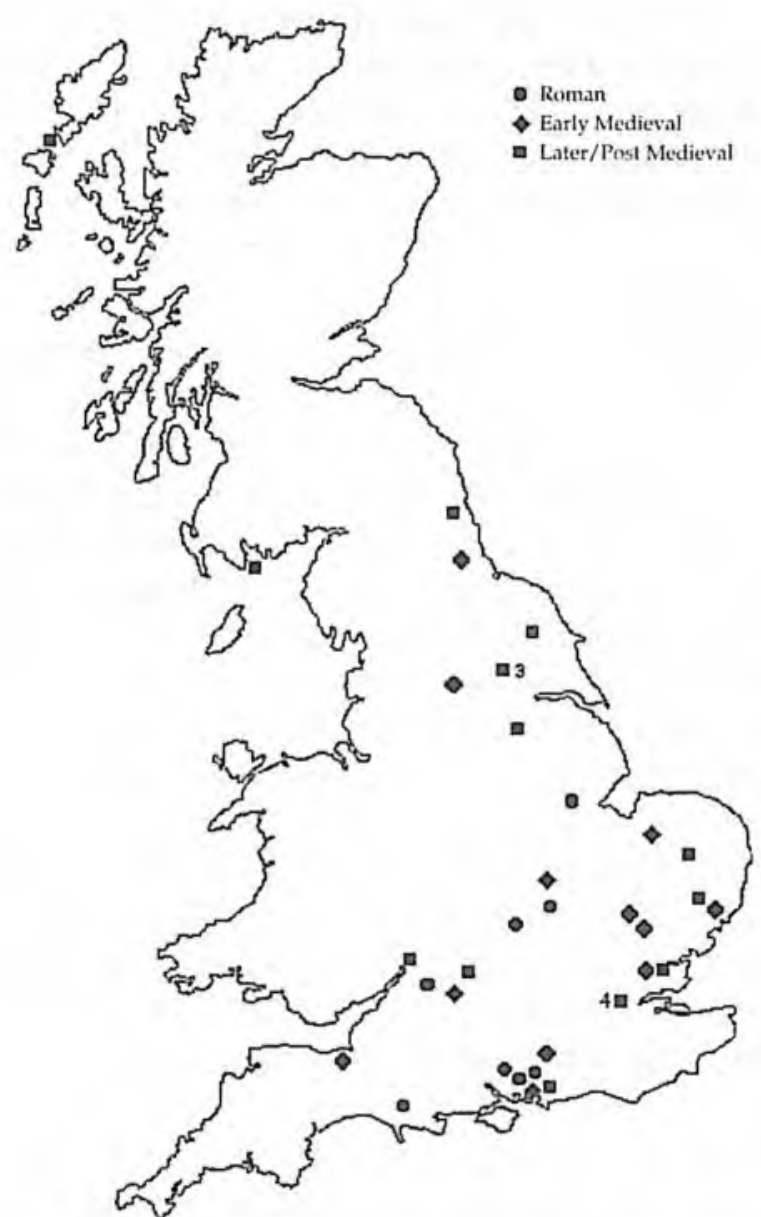

Figure 2. Distribution of cases of tuberculosis of the spine in Britain (Roman to late Medieval; numbers refer to number of sites in a particular place with tuberculosis evidence) - Prepared by Yvonne Beadnell, University of Durham. 


\section{Roman}

While 15 individuals from the prehistoric period have revealed new bone formation on ribs (as early as the Neolithic or c.40002500 BC) which may be TB induced, the earliest definitive examples of tuberculosis come from the Roman period and date to the $4^{\text {th }}$ century AD. However, Mays and Taylor (2003) has recently reported an Iron Age example from Tarrant Hinton, Dorset (400-230 BC). Eleven individuals from 8 sites are affected. In addition, 35 individuals from 12 sites had periostitis on their rib surfaces, representing pulmonary infection, possibly tuberculous. Tuberculosis in the Roman period appears to be focused in the south and east, in both urban and rural settlements, and does not reach further north beyond Ancaster in Lincolnshire.

\section{Early Medieval}

For the early Medieval/Anglo-Saxon/Post-Roman period $\left(5^{\text {th }}-11^{\text {th }}\right.$ centuries AD) there seem to be similar numbers at 15 from 12 sites. An interesting individual from Northern England in Yorkshire, at the site of Addingham, was that of a male (25-35 years) with Pott's disease of the spine and new bone formation on the ribs. It was possible to positively confirm tuberculosis in this individual using both ancient DNA and mycolic acid analyses (Gernaey et al., 2001). From Sewerby, East Yorkshire, Hirst (1985) also describes an unusual finding that could relate to TB. A piece of calcified pleura from an elderly female was excavated and may well have been the result of tuberculosis, but could equally have been caused by a number of pulmonary diseases. Twenty-five individuals from 8 sites also had rib periostitis. Early Medieval sites revealing tuberculosis, again, therefore tend to cluster in the south and east, and do not go further north than Binchester in County Durham, a little further north than in the Roman period.

\section{Later and Post-Medieval}

In Later and Post-Medieval cemetery populations (12 ${ }^{\text {th }}$ century onwards) we see a further increase in cases to 52 from 20 sites; 138 individuals from 12 sites are also recorded with new bone 
formation on ribs. Most of the data comes from Later (late $11^{\text {th }}-16^{\text {th }}$ centuries AD) rather than Post-Medieval (16 ${ }^{\text {th }}$ century AD onward) sites as few Post-Medieval cemeteries have been excavated. At the Royal Mint site $\left(12^{\text {th }}-16^{\text {th }}\right.$ centuries AD), in London, from a total of 940 burials two were affected in their spines and three in their wrists (Waldron, 1993). Taylor et al. $(1996 ; 1999)$ have recently provided positive aDNA identification of tuberculosis for some of these examples. If one believes the documentary and art evidence for tuberculosis in London, particularly in the Later and PostMedieval periods, the figures actually recorded in the skeletal evidence are very low indeed, even accounting for the problem in palaeopathological diagnosis.

In Yorkshire, in York, at the Jewbury site, six of 412 individuals had tuberculous changes; all had spinal involvement with one male having associated hip changes (Brothwell and Browne, 1994). In view of the comments by Zias (1998) on the low frequency of tuberculosis in Jewish populations, these are interesting data. Even further north at the Newcastle Infirmary burial ground (dated to AD 1753-1845), despite documentary records recording that $27 \%$ of people there had died from tuberculosis, only two of 210 articulated burials showed classic tuberculous changes in their skeletons (Boulter et al., 1998 Gernaey et al., 1999). Gernaey et al. (1999) confirmed, through extraction of Mycobacterium tuberculosis mycolates, that, indeed, around one quarter of the people buried there had died from tuberculosis, illustrating the problems with identifying the true prevalence of tuberculosis solely from macroscopic changes in the skeleton.

\section{Discussion}

TB is present in Britain by the $1^{\text {st }}$ millennium $\mathrm{BC}$ but, on the basis of the skeletal evidence, it was by no means an epidemic. At that time it is focused in the south in major Roman urban settlements. In the early Medieval period, the evidence extends further north towards the Scottish border. Its location also extends to the south-west of 
England and Norfolk and Suffolk to the east. By the Late Medieval period, London and Scotland see the first cases.

While the Late and Post-Medieval cases seem more evenly spread throughout Britain and reach well up into Scotland, the frequencies are lower than would be expected. To consider these data with reference to the multiple factors that may predispose people to $\mathrm{TB}$, the following questions will be discussed:

- Where did TB in Britain originate?

- Were animals originally the focus for TB in humans in Britain?

- Why did TB become more common in the Later Medieval period?

\section{The origin of TB in Britain}

The earliest cases of TB are few and lie in the south of England. It is tempting to suggest that the infection entered Britain via trade and migration of people from the continent. We know that as early as the Later Bronze Age (1400-700 BC) that Channel crossings were being undertaken, which continue into the Iron Age. Research exploring the origin of the early cases of TB is ongoing but, until we have these results, we cannot develop the theory further. Of course, the transport of infected animals may have brought the disease across the Channel as easily as humans. The effects of migration of humans with TB into new areas where resistance to new diseases would be low, or contact with people with tuberculosis via trade, could enhance the possibility of tuberculosis being transmitted to new unexposed populations. Much research has documented the effect of travel and migration on health in living populations (Kaplan, 1988; Armelagos, 1990), and it is highly likely that movement of people in the past took tuberculosis to new areas of the world, as it does today.

If we take a closer look at the evidence for $\mathrm{TB}$ in the rest of Europe, we find the earliest evidence in Italy ( $6^{\text {th }}$ millennium $B C$ ), and in Neolithic Poland and Spain. Between the $2^{\text {nd }}$ and $5^{\text {th }}$ centuries AD Britain, Austria and Lithuania produce their first evidence (all referenced in Roberts and Buikstra, 2003). The 
appearance of $\mathrm{TB}$ in Britain does suggest a trans-Channel transmission from east to west, and we have clear evidence of Roman armies invading from the continent on a grand scale in the $1^{\text {st }}$ century AD (Frere, 1978).

\section{Were animals responsible for TB in the human population in Britain?} Until recently, we have assumed that animals were responsible for initial TB infection (Mycobncterim bovis) in humans with the advent of domestication (Figure 3). Later, it is thought that $M$. tuberculosis evolved from the bovine disease by adaptation of an animal pathogen to the human host. We might expect that in Britain humans may have been affected by both organisms, with perhaps sites later in time (Late Medieval and later) favouring $M$. tuberculosis due to higher population density. We might also expect that at rural sites more people would be infected with $M$. boois because of the close working relationship people would have had with their animals through farming. While research investigating this hypothesis is only in the early stages, recent research (Mays et al., 2001), admittedly based on one late rural Medieval site in Yorkshire, revealed that of those individuals with $T B$, none were infected with Mycobncterimm boois. If we are particularly interested in whether the early cases of TB in Britain were the result of contact with infected animals then aDNA analysis should now focus on them.

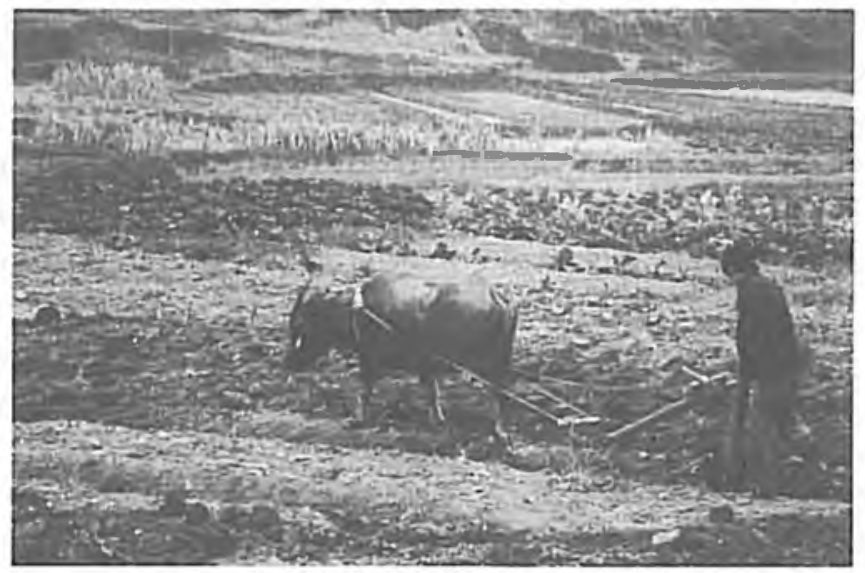

Figure 3. Ploughing in China using a traditional plough. 
Another assumption is that it was domesticated animals that transmitted TB to humans, but it is clear that this infectious disease can be contracted also by wild and feral animals (see above). Therefore, TB could have occurred earlier in animal and human populations than domestication. There is also research suggesting that mycobacterial species first appeared 15,300-20,400 years ago, long before domestication (Kapur et al., 1994). Furthermore, a recent published report (Rothschild et al., 2001) revealed Mycobacterium tuberculosis complex from bones with "tuberculosiscompatible pathology" from an extinct long horned bison dated to $17,870 \pm 230 \mathrm{BP}$ from North America (late Pleistocene). In fact, Sreevatsan et al.'s (1997) biomolecular work on the M. tuberculosis complex suggests that it was 15-20,000 years ago when the separation of $M$. tuberculosis and $M$. bovis occurred.

Closer contact of animals with each other, and with humans, at domestication would certainly have helped the disease to spread if it had been present in the population. The use of infected animals for food and industrial products such as bone and horn tools all could potentially harbour the mycobacterium. As communities developed and urban centres became established, populations increased and craft specialisation developed, leading to occupational risks of contracting TB. For example, working in tanneries may have exposed people to infected hides and other products, and any workplace that generated particulate pollution predisposed those who inhaled the air to develop tuberculosis because of lung tissue irritation.

The question of whether animals were the first to be affected by TB in Britain cannot be solved until more research has been done. However, we must take note of recent published research (Brosch et al., 2002), that has considered the genomic structure of tubercle bacilli. This has indicated that $M$. tuberculosis did not evolve from $M$. bovis. In Britain, animals may not have had anything to do with the appearance of TB, although later may have contributed to the TB load in populations. Unfortunately, there is, as yet, no archaeozoological evidence for TB in Britain to help us understand the relationship between animal and human TB through time. 


\section{Why did TB become more common in the late Medieval period?}

It was not until people started to settle in larger communities and population densities increased that tuberculosis could really become epidemic, and this happened in the Late Medieval period in Europe. We see a situation where many failings in infrastructure could quickly lead to TB establishing itself in populations. The following illustrates some of those failings in late Medieval Britain.

People living in close proximity to each other allowed TB to spread via droplets, and infect other members of the community (Figure 4). As Cohen (1989: 47) states, "... the survival and dissemination of any parasite is likely to be assisted by an increase in the number of available hosts", and so it was for tuberculosis. The development of trade, migration and contact brought further possibilities of infecting populations who had not been exposed to tuberculosis before, with immune systems that were not ready for what was to face them. From the Norman Conquest (AD 1066), for two centuries the population of England rapidly increased and became very overpopulated by the end of the $13^{\text {th }}$ century (Platt, 1997). Dyer (1998) also indicates that between AD 1066 and the Industrial Revolution there were three phases of population expansion. As he states, "living standards would tend to decline if the population rose to too high a level, through the shortage of

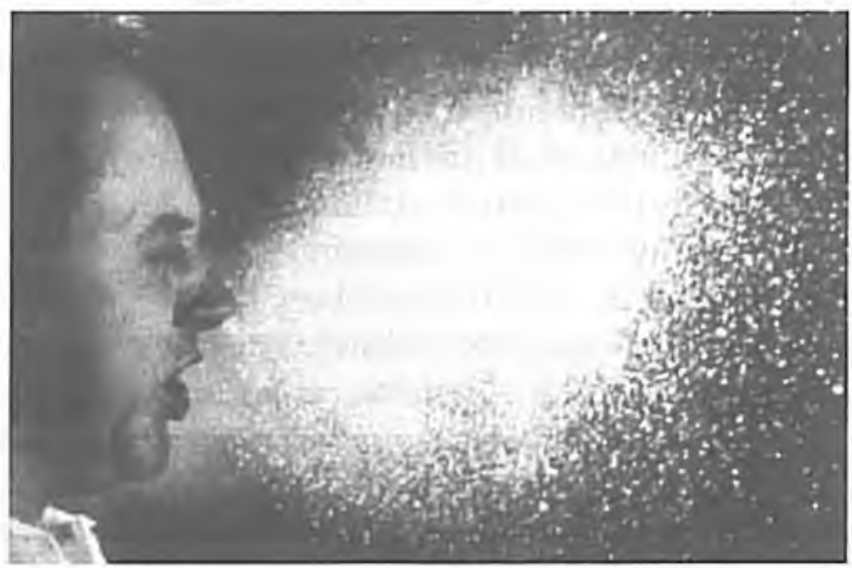

Figure 4. Sneezing, which illustrates how tuberculosis can potentially be transmitted via droplet infection (courtesy of Pia Bennike). 
production land and the depressed level of wages; and epidemics would bring in their wake cheap land and high wages". In the urban areas the $13^{\text {th }}$ century expansion of urbanism and population was followed by a later decline into the $15^{\text {th }}$ century (ibid: 189).

In rural areas houses during this period were stone walled constructions bounded with clay or earth from the late $12^{\text {th }}$ century, and where stone was scarce wooden framed structures rested on stone blocks, and walls were of wattle and daub or earth (ibid: 161). Roofs were made of straw, reeds or turf. Many peasants lived in long houses with their animals, thus providing an opportunity for droplet infection of TB of humans from animals. There were also few windows to these constructions, and the living area was divided into a sleeping room and a living room with a hearth where keeping warm and cooking would be served by the fire. Coal where available, peat in the north and west, and wood everywhere were the main sources of fuel.

In the urban situation during this time in England, houses were more tightly packed than in villages with little space between them. For example, Keene (1985 in Dyer, 1998) describes a population density in AD 1400 Winchester that is not matched by modern British urban standards. Privies often opened into open drains and cesspits, and heaps of animal manure accumulated in streets, while the water supply was potentially contaminated by domestic and industrial waste (Dyer, 1998: 189). While rural population densities were not as great as in towns and cities, there were some factors that would predispose people to TB such as low levels of hygiene and the presence of animals.

Of course, many health problems are related to quality and levels of nutrition, and tuberculosis is very much today associated with poverty and malnutrition. Once people become malnourished, their immune systems are compromised and they are more likely to contract disease - so it is for tuberculosis. In the case of secondary TB where re-infection or reactivation of primary $\mathrm{TB}$, a depressed immune system is key to development. Many authors have indicated that, with the development of agriculture, health generally may deteriorate (e.g. see Cohen and Armelagos, 
1984), diets become less varied and their nutritional content less balanced. Protein intake tends to decline and for tuberculosis resistance this created problems. Well balanced diets with high levels of protein (which produce the amino acids needed to make antibodies), and plenty of vitamins $A, C$ and $E$ were believed beneficial for the prevention and treatment of tuberculosis in $19^{\text {th }}$ and early $20^{\text {th }}$ century Europe (Knapp, 1989; Bardswell and Chapman, 1908). The decline in protein intake with the advent of agriculture probably exacerbated the tuberculosis problem. In addition, certain of the major cereal crops led to malnutrition. For example, wheat lacks certain amino acids (Cohen, 1989). Moreover, agriculture brought with it a decrease in vitamin $D$ intake which has been discussed as a possible aetiological factor in the development of tuberculosis in Asian populations migrating to the west today (Davies, 1995). Furthermore, with harvest failures, seasonal under- or malnutrition are real possibilities.

However, for many poverty was a way of life, thus predisposing people to disease and extreme hardship. However, as Dyer (1998: 235) states, the poor were valued by the rich, "... because alms-giving, an act of justice and mercy, wiped away sin, and the poor, for all of their low status on earth, kept the gates of heaven". Charity was given to the poor via establishing many hospitals in this period, and the benefits to these people in terms of food and care may have helped somewhat. Food was, of course, essential for life and health, and people in towns and the country depended on good harvests. However, during the late Medieval period there were times when the climate affected harvests and failures and deprivation followed. In the $13^{\text {th }}$ century the climate was mild and there was high winter rainfall. In the late $14^{\text {th }}$ and into the $15^{\text {th }}$ centuries, cold wet summers prevailed, becoming dryer and warm by 1500 (Dyer, 1998). Between 1550 and 1850 the "Little Ice Age" appears when there were shorter growing periods for cereals and conditions for cereal growing were poor. Harvest failures occurred in most of the $14^{\text {th }}$ century, with the worst time in the early years of 1315-1318. Added to this was the 1348-1349 AD plague that wiped out half the English population (Dyer, 1998). Many people also died from starvation and accompanying disease 
and, as towns depended on the country for their food, both town and country were affected. Thus, we have a situation in the Late Medieval period where poverty, intermittent famine, high population density and low hygiene levels were present by the $14^{\text {th }}$ century, just the situation for TB to develop as a major threat to human health.

If we also consider the hypotheses forwarded for the link between leprosy and tuberculosis, we would expect higher frequencies of TB in Late and Post-Medieval Britain. Leprosy and tuberculosis are considered to have a degree of cross-immunity. They are caused by the same Mycobacterilum genus but different species of the genus result in either leprae or tuberculosis. Leitman et al. (1997) considers that a species or strain of an organism may competitively exclude another from a host population over a long time period. Both leprosy and tuberculosis have a long and variable incubation period, have a propensity for sub-clinical infection and have a variety of clinical manifestations and transmission potential (Fine, 1984). They are also both associated with poverty and are stigmatised in human societies. Manchester (1991) indicates that, theoretically, tuberculosis buffers against leprosy and, if the conditions are right, tuberculosis will replace leprosy as a more virulent organism. Development of towns and cities created just those conditions for tuberculosis to thrive, leading to increased exposure to the tubercle bacillus and eventual immunity to leprosy. Occurring about the $14^{\text {th }}$ century AD in Europe, tuberculosis became the more dominant disease, with leprosy declining. However, as Leitman et al. (1997) suggest, eradication of leprosy in a population with tuberculosis could have taken centuries. Nevertheless, it is clear that tuberculosis could be expected to increase in the Later Medieval period due to changes in socio-economic circumstances, that is mainly in increased population density. If we take a look at the data for leprosy at the same time, we see a similar distribution pattern, again with the earliest evidence coming from the Roman period. Leprosy hospital foundations, however, do decline in the $14^{\text {th }}$ century although taking these data as an indication of a decline in the disease is problematic. Unfortunately it is not possible to discuss in detail 
what happens to leprosy and TB skeletal frequencies around the $14^{\text {th }}$ century AD because: 1 . Late Medieval stratigraphic sequences available do not allow us to specify when a person was buried (was it the $12^{\text {th }}, 13^{\text {th }}, 14^{\text {th }}$ or $15^{\text {th }}$ centuries?), and 2 . We cannot generate true frequencies for TB and leprosy from the data available. Thus, we cannot test the cross-immunity hypothesis directly. However, recent work by Wilbur et al. (2002) suggests that this hypothesis may not be as straightforward as we had believed. Preliminary analysis of incidence data for leprosy and TB in $20^{\text {th }}$ century Texas offers possible although not conclusive evidence against the cross-immunity hypothesis. On the basis of the data considered here the decline of leprosy as a result of tuberculosis in the $14^{\text {th }}$ century AD cannot be proved using the skeletal data.

\section{Conclusions}

"Most paleopathological studies report on isolated cases of tuberculosis or tuberculosis-like infections" (Larsen, 1997: 102).

On the basis of current data, there appears to have been an early focus for TB in the Mediterranean and Northern European areas. The early evidence of course points to an origin for humans in their domesticated animals although, as we have seen, this may not necessarily the case. However, no cases of TB have been identified in hunting and gathering populations, or in animal bones in these areas. Most of the evidence for TB in human populations does come from the later Medieval period and from the Northern European and Mediterranean areas. This was a time for most countries when populations were becoming much more aggregated, urbanism was developing fast, and people were often living in poverty while undertaking a variety of occupations that may have predisposed them to tuberculosis (including working with animals and their products). Britain is no different.

Clearly, during that Later Medieval period, tuberculosis had a good opportunity to establish itself in the population of Britain, following what had been sporadic infections prior to that time. It is 
likely that TB entered Britain through movement of people (and possibly animals) from the east across the English Channel, and the disease spread through the population as a result of increased population density, and contact through trade and travel. How responsible animals were for $\mathrm{TB}$ in human populations in Britain is still open to discussion. At this time in Britain, a range of variables had presented themselves within the environment of human populations which allowed tuberculosis to develop and increase in frequency. The decline of leprosy may have been stimulated by an increase in TB in the $14^{\text {th }}$ century but at present this is impossible to prove. Current work is concentrating on identifying the origin of early cases of TB in Britain and whether they were infected with M. tuberculosis or $M$. bovis.

\section{Acknowledgements}

Authors of published and unpublished British data apart from that collected by the author herself (data fully listed and referenced in Roberts and Buikstra, 2003).

\section{Bibliography}

Armelagos, G. J. 1990. Health and disease in populations in transition. In: SwedIund A. C.; Armelagos, G. J. (eds.). Disease in populations in transition. Antluropological nud epidentiological perspectives. New York, Bergin and Garvey: 127-145.

Bardswell, N. D.; Champion, J. E. 1908. Diets in tuberculosis. London, Oxford University Press.

Boulter, S.; Robertson, D. J.; Start, H. 1998. The Neweastle Infirmany at the Forth, Newcastle-upon-Tyme. Volume 2. The Osteology: people, disense and surgery. ARCUS Report 290. University of Sheffield, ARCUS.

Brosch, R.; Gordon, S. V.; Brodin, P. et al. 2002. A new evolutionary sequence for the Mycobacterimn tuberculosis complex. Procedtings of the National Acndemy of Science, 99 (6): 3684-3689.

Brothwell, D.; Browne, S. 1994. Pathology. In: Lilley, J. M.; Stroud, G.; Brothwell, D.; Williamson, M. H. (eds.). The Jetrish burial ground at 
Jetubury. The Archaeology of York. The Medieval Cemeteries 12/3. York, Council for British Archaeology for York Archaeological Trust: 457-494. Buikstra, J. E. (ed.) 1981. Prehistoric tuberculosis in the Americas. Evanston, Illinois, Northwestern University Archaeological Program.

Cohen, M. 1989. Health and the rise of civilisation. New Haven and London, Yale University Press.

Cohen, M.; Armelagos, G. (eds.) 1984. Palcopathology at the origins of agriculture. London, Academic Press.

Davies, P. D. O. 1995. Tuberculosis and migration. Joumal of the Royal College of Plysicinins of Lonton, 29:113-118.

Dyer, C. 1998. Standarts of living in the later Middle Ages. Social change in England c. 1200-1520. Revised edition. Cambridge, Cambridge University Press.

Farmer, P. 1999. Infections and inequalities. The modern plagues. Berkeley, University of California Press.

Fine, P. 1984. Leprosy and tuberculosis - an epidemiological comparison. Tubercle, 65:137-153.

Frere, S. 1978. Britammin. London, Routledge and Kegan Paul.

Gernaey, A.; Minnikin, D. E.; Copley, M.; Ahmed, A. M. S.; Roberston, D. J.; Nolan, J.; Chamberlain, A. T. 1999. Correlation of the occurrence of mycolic acids with tuberculosis in an archaeological population. In: Pálfi, G; Dutour, O.; Deák, J.; Hutás, I. (eds.) Tuberculosis: past and present. Budapest-Szeged, Golden Book - TB Foundation: 275-282.

Gernaey, A. M.; Minnikin, D. E.; Copley, M.; Dixon, R.; Middleton, J. C.; Roberts, C. A. 2001. Mycolic acids and ancient DNA confirm an osteological diagnosis of tuberculosis. Tuberculosis, 81(4): 259-265.

Haas, C. J.; Zink, A.; Molnár, E.; Marcsik, A.; Nerlich, A. G.; Pálfi, G. 1999.

Molecular evidence for tuberculosis in Hungarian skeletal samples. In: Pálfi, G; Dutour, O.; Deák, J.; Hutás, I. (eds.). Tuberculosis: past and present. Budapest-Szeged, Golden Book - TB Foundation: 385-391.

Hirst, S. 1985. An Anglo-Snxon imhunation cemetery at Sezuerby, East Yorkshive. York, University Archaeological Publications 4.

Inhorn, P. J.; Brown, M. C. 1990. The anthropology of infectious disease. Anmual Revicu of Antwropology, 19: 89-117.

Kaplan, B. 1988. Migration and disease. In: Maisie-Taylor C. G. N.; Lasker, G.W. (eds.). Biological aspects of human migration. Cambridge, Cambridge University Press: 216-245.

Kapur, V.; Whittam, T. S.; Musser, J. M. 1994. Is Mycobacterium tuberculosis 15,000 years old? Journal of Infectious Disease, 170:1348-1349. 
Keene, D. 1985. Survey of Medieval Wincliester. Two volumes. Oxford, Oxford University Press.

Knapp, V. J. 1989. Dietary changes and the decline of scurvy and tuberculosis in $19^{\text {th }}$ century Europe. New York State Joumal of Medicine, 89: 621-624.

Larsen, C. S. 1997. Bionchneology: interpreting behaviour through the skeleton. Cambridge, Cambridge University Press.

Leitman, T.; Porco, T.; Blower, S. 1997. Leprosy and tuberculosis: the epidemiological consequences of cross-immunity. American Journal of Public Health, 87(12): 1923-1927.

Manchester, K. 1991. Tuberculosis and leprosy: evidence for interaction of disease. In: Ortner, D. J.; Aufderheide, A. (eds.). Human paleopathology. Current syntheses and future options. Washington D. C., Smithsonian Institution Press: 23-35.

Mays, S.; Taylor, G. M.; Legge, A. J.; Young, D. B.; Turner-Walker, G. 2001. Paleopathological and biomolecular study of tuberculosis in a Medieval skeletal collection from England. American Joumal of Physical Anthropology, 114(4): 298-311.

Mays, S.; Taylor, G. M. 2003. A first prehistoric case of tuberculosis from Britain. Intemational Joumal of Osteonichneology, 13: 189-196.

Platt, C. 1997. Mediezal England. A social history and archneology from the Conquest to $1600 \mathrm{AD}$. London, Routledge.

Powell, M. L. 1988. Status and health in prehistory. A case study of the Moundville Chiefiom. Washington D.C., Smithsonian Institution Press.

Resnick, D. (ed.) 1995. Dingnosis of bone and joint disorders. Edinburgh, W.B. Saunders.

Resnick, D.; Niwayama, G. 1995. Osteomyelitis, septic arthritis and soft tissue infection: axial skeleton. In: Resnick, D. (ed.). Diagnosis of bone and joint disorders. Edinburgh, W.B. Saunders: 2419-2447.

Roberts, C. A. 1999. Rib lesions and tuberculosis: the current state of play. In: Pálfi, G; Dutour, O.; Deák, J.; Hutás, I. (eds.). Tuberculosis: past and present. Budapest-Szeged, Golden Book - TB Foundation: 311-316.

Roberts, C. A.; Buikstra, J. E. 2003. The bioarchneology of tuberculosis: a global perspective on a re-enterging disense. Gainesville, University Press of Florida.

Rothschild, B. M.; Martin, L. D.; Lev, G.; Bercovier, H.; Bar-Gal, G. K.; Greenblatt, C.; Donoghue, H.; Spigelman, M.; Brittain, D. 2001. M. tuberculosis complex DNA from an extinct bison dated 17,000 years before the present. Clinical Infectious Diseases, 33: 305-311. 
Santos, A. L. 2000. A skeletal picture of tuberculosis. Macroscopic, radiological, biomolecular, and historical evidence from the Coimbra Identified Skeletal Collection. Dissertação de Doutoramento em Antropologia Biológica, Departamento de Antropologia, Universidade de Coimbra.

Santos, A. L.; Roberts, C. A. 2001. A picture of tuberculosis in young Portuguese people in the early $20^{\text {th }}$ century: a multidisciplinary study of the skeletal and historical evidence. American Journal of Plyysical Antliropology, 115(1): 38-49.

Schultz, M. 1999. The role of tuberculosis in infancy and childhood in prehistoric and historic populations. In: Pálfi, G; Dutour, O.; Deák, J.; Hutás, I. (eds.). Tuberculosis: past and prescnt. Budapest-Szeged, Golden Book-TB Foundation: 503-507.

Sreevatsan, S.; Escalante, P.; Pan, X.; Gillies II, D. A. ct al. 1997. Identification of a polymorphic nucleotide in oxy $\mathrm{R}$ specific for Mycobacterium bovis. Joumal of Clinical Microbiology, 34: 2007-2010.

Taylor, M.; Crossey, M.; Saldanha, J.; Waldron, T. 1996. DNA from M. tuberculosis identified in Medieval human skeletal remains using PCR. Joumal of Archneological Science, 23: 789-798.

Taylor, G. M.; Goyal, M.; Legge, T.; Shaw, A. J.; Yound, D. 1999. Genotypic analysis of Mycobncterium tuberculosis from Medieval human remains. Microbiology, 145: 899-904.

Waldron, T. 1993. Dinft report on the Inman remains from the Royal Mint site (MIN 86). London, MOLAS Archive HUM/07/93.

Wilbur, A.; Buikstra, J. E.; Stojanowski, C. 2002. Mycobacterial disease in North America: an epidemiological test of Chaussinand's crossimmunity hypothesis. In: Roberts, C.; Lewis; M.; Manchester K. (eds.). The past and present of leprosy. Archaeological, historical, palaeopathological and clinical approaches. Oxford, Archaeopress: 247-258. (British Archaeological Reports. International Series; 1054).

Wood, J. W.; Milner, G. R.; Harpending, H. C.; Weiss, K. M. 1992. The osteological paradox: problems of inferring prehistoric health from skeletal samples. Current Anthropology, 33(4): 343-370.

Zias, J. 1998. Tuberculosis and the Jews in the ancient Near East: the biocultural interaction. In: Greenblatt, C. L. (ed.). Digging for pathogens: Ancient emerging diseases - their colutionary, anthropological and archacological context. Rehovot, Balaban Publishers: 277-297. 